\title{
SPEAKING TO REMAIN SILENT: IMPLIED WAIVERS AND THE RIGHT TO SILENCE AFTER BERGHUIS
}

\author{
Zachary Mueller*
}

\begin{abstract}
No person shall be compelled in any criminal case to be a witness against himself.

- Fifth Amendment, U.S. Constitution ${ }^{1}$

Protecting the rights of even the least individual among us is basically the only excuse the government has for even existing.

- Ronald Reagan ${ }^{2}$

The privilege [against self-incrimination], while sometimes "a shelter to the guilty," is often "a protection to the innocent."

- Murphy v. Waterfront Commission ${ }^{3}$
\end{abstract}

It is a curious feature of our criminal justice system that suspects wishing to exercise their Fifth Amendment right to silence must first speak up. ${ }^{4}$ This requirement hardly seems intuitive given the content of the standard Miranda warning: "You have the right to remain silent. Anything you say can and will be used against you in a court of law ...." In practice, however, silence is often

\footnotetext{
* Juris Doctor, University of Pittsburgh School of Law, 2012. I offer my eternal gratitude to my family for their unconditional love and support; to my law school friends, who always fostered a good debate; and to the editors of the University of Pittsburgh Law Review, whose fastidiousness significantly improved the quality of this article.

${ }^{1}$ U.S. CONST. amend. V.

${ }^{2}$ Ronald Reagan, Governor of Cal. and President of the U.S., Governor's Speech during "Operation Cable Splicer" at the Governor's Orientation (Feb. 10, 1969).

${ }^{3}$ Murphy v. Waterfront Comm'n of N.Y. Harbor, 378 U.S. 52, 55 (1964).

${ }^{4}$ Berghuis v. Thompkins, 130 S. Ct. 2250, 2260 (2010).

${ }^{5}$ See Arizona v. Miranda, 384 U.S. 436, 442-46 (1966).
} 
interpreted by the police as acquiescence to questioning, and suspects who remain silent in the belief that they are triggering their rights do so at their own peril. ${ }^{6}$ Any statement a suspect makes - even a one-word remark after three hours of silenceprobably constitutes a waiver of the Fifth Amendment privilege. ${ }^{7}$ In practice, then, a simple response to a police question after hours of fruitless inquiry may be sufficient to impose a life sentence upon the accused. ${ }^{8}$ This is, indeed, the state of the Supreme Court's Fifth Amendment jurisprudence.

The ease with which modern courts find valid waivers of the Fifth Amendment privilege reflects decades of post-Miranda Supreme Court decisions that have diminished the government's burden in proving waiver. ${ }^{9}$ In particular, the creation of the implied waiver doctrine now permits courts to infer that a defendant waives the right to silence by engaging in a "course of conduct indicating waiver." 10 Since the inception of this principle, the Supreme Court's Miranda jurisprudence has made invocation of the right to silence so difficult and waiver so easy that the burden has been effectively placed on the defendant to prove invocation rather than on the prosecution to prove waiver. ${ }^{11}$ For example, interrogators can simply begin questioning without asking suspects whether they

\footnotetext{
${ }^{6}$ See Berghuis, 130 S. Ct. at 2260 (noting that there is "good reason" to require the accused to invoke the right to silence in an unambiguous manner). The Court's Berghuis opinion reaffirmed numerous lower court decisions requiring suspects to affirmatively invoke the right to silence. See, e.g., James v. Marshall, 322 F.3d 103, 108-09 (1st Cir. 2003) (analyzing whether the defendant invoked his right to silence unambiguously); Simmons v. Bowersox, 235 F.3d 1124, 1131 (8th Cir. 2001) (asking whether defendant made unequivocal assertion of the right to remain silent).

${ }^{7}$ Berghuis, $130 \mathrm{~S}$. Ct. at 2263 (concluding that the defendant's one-word response to police after three hours of unsuccessful interrogation constituted a "course of conduct indicating waiver") (quoting North Carolina v. Butler, 441 U.S. 369, 373 (1979)).

${ }^{8}$ Pursuant to the Court's Berghuis decision denying Thompkins's habeas claim, Thompkins's sentence of life without parole was upheld. The District Court's opinion, including Thompkins's initial sentence, is reported at Thompkins v. Berghuis, No. 05-70188, 2006 WL 3086916 (E.D. Mich. Oct. 30, 2006).

${ }^{9}$ See, e.g., Colorado v. Spring, 479 U.S. 564, 574 (1987) (ruling that valid waiver does not require that suspects know and understand every possible consequence of waiving the privilege against selfincrimination); Moran v. Burbine, 475 U.S. 412, 421 (1986) (holding that suspect may waive his rights even though he is unaware that a lawyer has been retained for him).

${ }^{10}$ Butler, 441 U.S. at 373 (1979).

${ }^{11}$ See generally Richard A. Leo, Questioning the Relevance of Miranda in the Twenty-First Century, 99 MiCH. L. REV. 1000, 1018 (2001) (noting that by responding to an interrogator's questions by saying nothing or answering the questions, a suspect is said to have implicitly waived his rights).
} 
wish to assert their rights; if suspects respond to questioning by saying nothing, they are presumed to have made an implied waiver. ${ }^{12}$

This note explores the origins and purposes of the implied waiver doctrine and proposes a contemporary rule that attempts to strike the proper balance between society's interest in obtaining valid confessions and a defendant's interest in securing his constitutional rights. This analysis is divided into three parts. Part I addresses the framework established by the Court's Miranda decision and postMiranda trends relating to custodial interrogation and waiver. Part II traces the growth and development of the implied waiver doctrine, with a particular emphasis on the types of conduct that courts have found to constitute waiver. Finally, Part III argues that the underlying purposes of Miranda can only be fulfilled by limiting the implied waiver doctrine. Specifically, implied waivers should be limited to circumstances in which defendants do not explicitly waive their rights but engage in conversation with interrogating officers immediately after the Miranda warnings are given.

\section{The Purpose And Consequences of Miranda}

The expressed purpose of Miranda is to provide law enforcement with concrete procedural guidelines to preserve the accused's constitutional rights and to relieve persons taken into custody of the inherent coercive pressures of police interrogations. ${ }^{13}$ To this end, police must inform suspects prior to questioning that (1) they have the right to remain silent; (2) their statements may be used against them at trial; (3) they have the right to an attorney; (4) they have the right to an appointed attorney if they cannot otherwise afford counsel. ${ }^{14}$

The Court chose to adopt this prophylactic rule in response to the perceived dangers of contemporaneous interrogation practices. ${ }^{15}$ First, the Court was concerned that the process of custodial interrogation presented inherent pressures to compel suspects to speak. ${ }^{16}$ Second, the Court worried, on an abstract level, that police-dominated interrogations in environments unfamiliar to the accused were destructive of human dignity. ${ }^{17}$ This idea supplemented the Court's opinion that

\footnotetext{
${ }^{12} I d$.

${ }^{13}$ Miranda v. Arizona, 384 U.S. 436, 442-46 (1966).

${ }^{14} I d$. at $478-79$.

${ }^{15} I d$. at 446 (noting that, at the time, police often resorted to violence to obtain confessions).

${ }^{16}$ Charles D. Weisselberg, Mourning Miranda, 96 CALIF. L. ReV. 1519, 1522 (2008).

${ }^{17}$ Miranda, 384 U.S. at 457.
} 
coercion can be both mental and physical, and that "the blood of the accused is not the only hallmark of an unconstitutional inquisition." 18 The process of interrogation is itself intricately designed to induce stress and anxiety, leading suspects to believe that the apparent hopelessness of the situation will only be alleviated by making a statement. $^{19}$

The Miranda Court determined that protecting the accused from the pressures of custodial interrogation required not only that a suspect be advised of his rights, but also that the prosecution overcome a heavy burden in proving that the accused waived his rights. ${ }^{20}$ Specifically, the government must show that an accused's waiver was made knowingly, intelligently, and voluntarily. ${ }^{21}$ Moreover, the Court held that the accused can invoke the right to silence in any manner, at any time. ${ }^{22}$

The government, then, faces a demanding burden in proving that the accused has made a valid waiver. ${ }^{23}$ In part, this heavy burden stems from the significant latitude given to the accused to invoke the Miranda protections at any time and in any manner. ${ }^{24}$ The Court's instructions regarding the suspect's invocation of rights were unusually explicit. By allowing suspects to assert their rights in any manner, the Court did not place any burden on the accused to demonstrate, for example, that invocation was unequivocal or unambiguous. ${ }^{25}$

Given this basic framework, it was reasonable to assume that more criminal suspects would take advantage of Miranda after the Court's ruling in 1966. Suspects would now have the benefit of being appraised of their rights upon arrest while also being provided with the opportunity to remain silent and secure counsel. Indeed, the dissent predicted that "a good many criminal defendants who otherwise would have been convicted ... will now either not be tried at all or will be acquitted .... ${ }^{26}$ In the days and months after the ruling was announced, critics

\footnotetext{
${ }^{18}$ Id. at 448 (quoting Blackburn v. State of Alabama, 361 U.S. 199, 206 (1960)).

${ }^{19}$ Weisselberg, supra note 16, at 1537.

${ }^{20}$ Miranda, 384 U.S. at 475.

${ }^{21}$ Id. at 444 .

${ }^{22} I d$. at 445 (emphasis added).

${ }^{23} \mathrm{Id}$. at 475 .

${ }^{24} I d$. at 445 .

${ }^{25}$ The court noted, for instance, that "where the assistance of counsel is a constitutional requisite, the right to be furnished counsel does not depend on a request." Id. at 471 (quoting Carnley v. Cochran, 369 U.S. 506, 513 (1962)).

${ }^{26} I d$. at 542 (White, J., dissenting).
} 
argued that, given the heightened requirements on law enforcement to ensure that suspects were aware of their rights, the decision would debilitate law enforcement efforts to extract confessions and secure convictions. ${ }^{27}$

Nearly five decades later, however, the concerns of Miranda's critics have never materialized. ${ }^{28}$ While social scientists and legal scholars gathered very little data on the effects of Miranda in the period immediately following the decision, more recent research suggests that nearly eighty-five percent of suspects waive their Miranda rights; of those, eighty percent waive their rights before police even begin questioning. ${ }^{29}$ The data also show that more than forty percent of suspects end up making an incriminating statement. ${ }^{30}$ How have the police been so successful in spite of Miranda? Why are suspects so willing to agree to questioning, especially when they are likely to give a confession that could result in a significant punishment?

There are two primary explanations for the post-Miranda trends toward valid waivers and successful interrogations. First, law enforcement agencies at the national and local levels have become adept at training their officers to overcome the obstacles posed by Miranda. ${ }^{31}$ Even though Miranda prohibits questioners from inducing waivers through trickery or cajolery, ${ }^{32}$ interrogators have designed and adopted numerous interrogation techniques that have proven to be especially effective. ${ }^{33}$ For instance, interrogators often de-emphasize the significance of the Miranda warning by engaging the accused in small talk or insisting that the warning is merely a formality that can be - and should be - disregarded by the suspect. ${ }^{34}$ In some cases, officers lecture the suspect on the importance of telling

\footnotetext{
${ }^{27}$ See id.; Richard A. Leo \& Welsh S. White, Adapting to Miranda: Modern Interrogation Strategies for Dealing with the Obstacles Posed by Miranda, 84 MinN. L. REV. 397, 401 (1999).

${ }^{28}$ See generally Paul G. Cassell \& Bret S. Hayman, Police Interrogation in the 1990s: An Empirical Study of the Effects of Miranda, 43 UCLA L. REV. 839 (showing that the overwhelming majority of criminal suspects waive their rights).

${ }^{29} I d$. at 859.

${ }^{30} I d$. at 868 .

${ }^{31}$ See, e.g., David Zulawski \& Douglas Wicklander, Practical Aspects of InTerview and INTERROGATION 23-24, 36-39 (1993) (noting the significance of the interrogator assuming the role of "mediator negotiator").

${ }^{32}$ Miranda v. Arizona, 384 U.S. 436, 476 (1966).

${ }^{33}$ See Leo \& White, supra note 27, at 431-50 (noting the various strategies employed by interrogators to induce Miranda waivers).

${ }^{34}$ See id. at 433 .
} 
U N I V E R S I T Y O F P I T T S B U R G H L A W R E V I E W

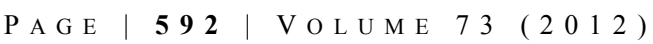

"his side of the story." 35 One of the most powerful tools in the interrogator's arsenal is the standard practice of offering suspects benefits in exchange for a waiver. ${ }^{36}$ Some officers convince suspects that they can find out what charges they face only by first waiving their rights; in other circumstances, officers describe the overwhelming trove of evidence already gathered against the accused. ${ }^{37}$ Finally, even when suspects invoke their rights, interrogators have established methods to circumvent the termination of questioning. In some situations, interrogators pretend to misunderstand a suspect who has invoked Miranda. ${ }^{38}$ Suspects who have effectively exercised their Miranda rights are often encouraged to think about their decisions and determine whether they would like to change their minds and cooperate with their questioners. ${ }^{39}$

These well-documented police practices-designed for the purpose of bypassing the requirements of Miranda - are important for several reasons. First, by prolonging interrogations after the accused has signaled a desire to exercise his Miranda rights, law enforcement officials explicitly violate the Miranda Court's "clear" procedural requirement that the interrogation cease when the accused indicates that he wishes to remain silent. ${ }^{40}$ Furthermore, a defendant who unsuccessfully attempts to invoke his Miranda rights is likely to believe that any further invocation is futile because the police will persist in their effort to extract a confession, notwithstanding the accused's expressed intent to end the interrogation. ${ }^{41}$ Finally, the continuation of questioning provides the police with more opportunities to obtain a confession, which, of course, has serious implications for the accused. In short, Miranda has not left law enforcement shackled and hopeless; far from the perceived world of the guilty-gone-free, Miranda has not significantly curtailed police efforts at obtaining confessions and securing convictions.

The second explanation for post-Miranda trends in favor of valid waivers and successful interrogations is the proliferation of court decisions making it more

${ }^{35}$ Id. at 435. See also DAVID Simon, Homicide: A YeAr on the Killing Streets 201 (1991).

${ }^{36}$ Leo \& White, supra note 27 , at 440.

${ }^{37} I d$.

${ }^{38} I d$. at 449.

${ }^{39}$ Charles D. Weisselberg, Saving Miranda, 84 CORNELL L. REV. 109, 189 (1998).

${ }^{40}$ Miranda v. Arizona, 384 U.S. 436, 474 (1966).

${ }^{41}$ Davis v. United States, 512 U.S. 452, 474-75 (1994). 
difficult for suspects to exercise their Miranda rights. ${ }^{42}$ The waiver regime envisioned by Miranda's drafters favored the accused by placing a heavy burden on the government to prove a knowing and voluntary waiver. ${ }^{43}$ In effect, the prosecution would face the same standard handed down by the Court in Johnson $v$. Zerbst, a case concerning the right to counsel: whether the accused intentionally relinquished or abandoned a known right or privilege. ${ }^{44}$ This test presumes that the accused is aware of the consequences of forgoing his rights, for it stands to reason that a person cannot intentionally relinquish a known right without comprehending the consequences of that right's exercise or abandonment. ${ }^{45}$ The Miranda Court, then, established a waiver test that requires a suspect to both understand the substance of the right to silence and right to counsel and the consequences of relinquishing those rights. ${ }^{46}$

In the years following Miranda, however, this rigid waiver system was gradually diluted by decisions easing the government's burden to prove waiver. For instance, the Supreme Court has held that the government only needs to demonstrate that a suspect understood the meaning of the rights to silence and counsel, not the consequences of abandoning them; furthermore, a suspect can knowingly and voluntarily waive the Miranda privileges without being informed that a lawyer has been appointed to represent him. ${ }^{47}$ Police tactics aimed at inducing waivers have withstood Miranda's prohibition against trickery or cajolery through application of a "totality of the circumstances test" to evaluate the voluntariness of waivers. ${ }^{48}$ This approach to voluntariness suggests that the use of certain prohibited police practices will not alone render a waiver invalid. Rather, in applying the totality framework, the court will weigh several factors: the

\footnotetext{
${ }^{42}$ See, e.g., Colorado v. Spring, 479 U.S. 564, 574 (1987) (ruling that valid waiver does not require that suspects know and understand every possible consequence of waiving the privilege against selfincrimination); Moran v. Burbine, 475 U.S. 412, 421 (1986) (holding that suspect may waive his rights even though he is unaware that a lawyer has been retained for him); Colorado v. Connelly, 479 U.S. 157,169 (1986) (holding that a waiver does not necessarily have to be the product of free will in order to be valid).

${ }^{43}$ North Carolina v. Butler, 441 U.S. 369, 373 (1979).

${ }^{44}$ See Miranda, 384 U.S. 475; Johnson v. Zerbst, 304 U.S. 458, 464 (1938).

${ }^{45}$ See Faretta v. California, 422 U.S. 806, 835 (1975) (noting that before a defendant can waive the right to counsel at trial, he must be informed of the risks of self-representation).

${ }^{46}$ Miranda, 384 U.S. at 475.

${ }^{47}$ See Spring, 479 U.S. at 574; Moran, 475 U.S. at 421.

${ }^{48}$ See, e.g., Connelly, 479 U.S. at 169 (1986).
} 
U N I V E R S I T Y O F P I T T S B U R G H L A W R E V I E W

PAGE

characteristics of the suspect, the context of the interrogation, and the overall conduct of the interrogators. ${ }^{49}$ Moreover, the use of "softening up" tactics and strategies designed to overcome a suspect's resistance to questioning suggests that courts have granted interrogators significant leeway during questioning. In this regard, lower courts have been especially permissive; no court has held that police are prohibited from using persuasive techniques to induce waivers. ${ }^{50}$

The creation of the implied waiver doctrine, however, was perhaps the most important post-Miranda event-the catalyst for the dissolution of the Miranda waiver regime. ${ }^{51}$ Once the Supreme Court ruled that a suspect may forgo his rights through any conduct evidencing waiver, the stage was set for a renewed assessment of Miranda's foundations.

\section{IMPLIED WAIVER DOCTRINE: ORIGINS AND FALLOUT}

There is reason to believe that at the time Miranda became law, interrogators were prohibited from questioning suspects in the absence of a valid waiver. ${ }^{52}$ By its own terms, Miranda requires law enforcement officials to cease questioning when the accused indicates that he wishes to remain silent. ${ }^{53}$ Questioning must also end when a suspect requests the assistance of counsel. ${ }^{54}$ Not only does the presumption favor the accused, but the Miranda court repeatedly emphasized that the pressures inherent in custodial interrogation could only be dispelled if the accused has "a full opportunity to exercise the privilege against self-incrimination" by being informed of his rights and having the exercise of those rights honored. ${ }^{55}$

Several decisions following Miranda, however, made it clear that police are free to continue questioning, even if a suspect invokes the right to silence or asks for an attorney. For instance, in Michigan v. Mosley, the Supreme Court upheld the admissibility of an incriminating statement rendered during a second interrogation two hours after the defendant invoked his right to remain silent. ${ }^{56}$ Noting that the

\footnotetext{
${ }^{49}$ See, e.g., United States v. Lynch, 92 F.3d 62, 65 (2d Cir. 1996); United States v. Anderson, 929 F.2d 96, 99 (2d Cir. 1991).

${ }^{50}$ Leo \& White, supra note 27, at 419.

${ }^{51}$ See infra Part II.

${ }^{52}$ Miranda v. Arizona, 384 U.S. 436, 473-74 (1966).

${ }^{53} \mathrm{Id}$.

${ }^{54} I d$.

${ }^{55}$ Id. at 467.

${ }^{56}$ See Michigan v. Mosley, 423 U.S. 96, 104 (1975).
} 
second line of questioning began after a significant period of time and involved a different crime, the Court concluded that the defendant's rights were "scrupulously honored," and thus, his inculpatory remarks relating to the first crime (made during the second interrogation) were admissible. ${ }^{57}$

In practice, the "scrupulously honored" test does not vary significantly from the original Miranda requirement of a knowing, voluntary, and intelligent waiver. ${ }^{58}$ In any event, Mosley does exemplify the principle that police may persist in questioning even in the absence of a formal waiver or after the accused properly invokes Miranda. This point should not be understated. At the beginning of questioning, a suspect exists in a kind of no-man's land: he has neither exercised nor surrendered his rights. This leaves the police with significant power to manipulate the situation in a way that makes successful questioning more likely. The creation of the implied waiver doctrine only magnifies this reality because, by acknowledging that suspects may waive their rights through a "course of conduct indicating waiver," the Court broadened the scope of conduct that constitutes waiver. $^{59}$

Implied waivers find their origin in North Carolina v. Butler.$^{60}$ In Butler, the Court upheld the validity of a confession volunteered by the defendant after he orally acknowledged that he understood his rights, and did not explicitly waive them, but agreed to cooperate with the interrogating officers. ${ }^{61}$ The defendant refused to sign an "Advice of Rights" form but later remarked that he would talk with FBI Agents. ${ }^{62}$ The Court interpreted Miranda to mean that express or oral statements of waiver, while "strong proof" of the validity of waiver, are not essential to a finding of waiver; rather any "course of conduct indicating waiver" is sufficient to establish that the accused has surrendered his rights. ${ }^{63}$

Lower courts have been quick to seize on Butler's ultimate holding. Since the 1979 decision, every federal court of appeals has upheld the admissibility of

\footnotetext{
${ }^{57}$ Id.

${ }^{58}$ Leo \& White, supra note 27 , at 425.

${ }^{59}$ The defendant in Thompkins, for example, made a one-word "yes" response to a question directed at him three hours after interrogation began. Berghuis v. Thompkins, 130 S. Ct. 2250, 2257 (2010).

${ }^{60} 441$ U.S. 369 (1979).

${ }^{61}$ Id. at 371 .

${ }^{62} I d$.

${ }^{63}$ Id. at 373 .
} 
statements falling under the category of implied waiver. ${ }^{64}$ But Butler is not the natural or inevitable consequence of Miranda. In particular, the Court's opinion in Miranda took pains to reaffirm that waiver could never be presumed from the silence of the accused or from the fact that the accused eventually makes a confession. ${ }^{65}$ Distinguishing between situations in which the accused has engaged in a course of conduct indicating waiver before confessing and situations in which the accused has not engaged in a course of conduct indicating waiver before confessing is an unenviable task: it is a fact-sensitive inquiry, and no circumstance is singularly dispositive.

In attempting to provide guidance on what constitutes a valid waiver of a suspect's Fifth Amendment rights, courts have turned to the initial question of what constitutes invocation of those same rights. ${ }^{66}$ The relationship between invocation and waiver proves to be vital because once a suspect insufficiently invokes his rights, any subsequent statement might constitute an implied waiver. ${ }^{67}$ Davis v. United States exemplifies this point quite nicely. ${ }^{68}$ While being investigated by the Naval Investigative Service, the defendant, Davis, waived his Miranda rights both orally and in writing. ${ }^{69}$ After ninety minutes of questioning, Davis said, "Maybe I should talk to a lawyer." 70 When interrogating agents clarified whether Davis actually wanted a lawyer, Davis responded that he did not, in fact, wish to have

\footnotetext{
${ }^{64}$ See United States v. Washington, 462 F.3d 1124, 1133-34 (9th Cir. 2006); United States v. Cardwell, 433 F.3d 378, 389-90 (4th Cir. 2005); Thai v. Mapes, 412 F.3d 970, 976-77 (8th Cir. 2005); Bui v. DiPaolo, 170 F.3d 232, 240-41 (1st Cir. 1999); United States v. Gell-Iren, 146 F.3d 827, 830 (10th Cir. 1998); United States v. Banks, 78 F.3d 1190, 1199 (7th Cir. 1996); United States v. Scarpa, 897 F.2d 63 , 67-69 (2d Cir. 1990); United States v. Manderson, 904 F.2d 78, 78 (D.C. Cir. 1990); United States v. Gonzalez, 833 F.2d 1464, 1466 (11th Cir. 1987); United States v. McKinney, 758 F.2d 1036, 1044-45 (5th Cir. 1985); United States v. Velasquez, 626 F.2d 314, 319-20 (3d Cir. 1980); United States v. Stark, 609 F.2d 271, 273 (6th Cir. 1979). See also Weisselberg, supra note 16, at 1582.

${ }^{65}$ Miranda v. Arizona, 384 U.S. 436, 475 (1966). See also Carnley v. Cochran, 369 U.S. 506, 516 (1962) ("Presuming waiver from a silent record is impermissible. The record must show, or there must be an allegation and evidence which show, that an accused was offered counsel but intelligently and understandingly rejected the offer. Anything less is not waiver.").

${ }^{66}$ See, e.g., Davis v. United States, 512 U.S. 452 (1994).

${ }^{67}$ See id. at 462 (explaining that the defendant did not properly invoke his right to counsel where he made only an ambiguous statement and that in the absence of a valid invocation, the defendant's actions and words indicated his intent to waive his rights).

${ }^{68} I d$.

${ }^{69} I d$. at 455 .

${ }^{70} I d$.
} 
counsel present. ${ }^{71}$ The agents continued questioning until Davis asked, unequivocally, for the assistance of an attorney. ${ }^{72}$ The Court rejected Davis' argument that the agents were required to cease questioning after the first, ambiguous request for counsel; to the contrary, the Court held that a proper invocation of the right to counsel requires a suspect to make an "unambiguous or unequivocal" request. ${ }^{73}$

As an initial matter, the Davis decision contradicts the Miranda Court's holding that suspects may invoke their rights in any manner and at any time. ${ }^{74}$ The Davis decision also places on suspects the burden of exercising their rights in a fashion that is not immediately apparent from the Miranda warnings. The warnings themselves merely advise suspects that they have the right to the assistance of counsel $;{ }^{75}$ there is no corollary instruction regarding the limited means by which the accused can exercise this right.

Even after the Davis opinion, there was reason to believe that Miranda would remain largely intact. By its own terms, Davis appears to govern only those cases in which suspects first waive their rights before attempting to invoke them. ${ }^{76}$ The Court in Davis confronted a situation in which a suspect effectively waived his Miranda rights, cooperated with police for ninety minutes, made an ambiguous request for an attorney, but then continued to talk with the police in the absence of counsel. ${ }^{77}$ The Court held that "[a]fter a knowing and voluntary waiver, law enforcement officers may continue questioning until and unless the suspect clearly requests an attorney." ${ }^{, 78}$ In effect, the Court limited its decision to scenarios in which the suspect consents to questioning before reconsidering the prudence of cooperating in the absence of a lawyer. At this stage in the questioning, the accused has acknowledged his understanding of the right to remain silent and the right to

\footnotetext{
${ }^{71} I d$.

${ }^{72} I d$.

${ }^{73}$ Id. at 459 .

${ }^{74}$ See Miranda v. Arizona, 384 U.S. 436, $444-45$ (1966).

${ }^{75} \mathrm{Id}$. at 444 .

${ }^{76}$ Davis, 512 U.S. at 461 ("We therefore hold that, after a knowing and voluntary waiver of the Miranda rights, law enforcement officers may continue questioning until and unless the suspect clearly requests an attorney.").

${ }^{77} I d$. at 455 .

${ }^{78}$ Id. at 461 (emphasis added).
} 
U N I V E R S I T Y O F P I T T S B U R G H L A W R E V I E W

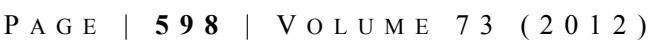

counsel, thereby alleviating the initial pressures inherent in custodial interrogation. $^{79}$

Davis, moreover, concerned the right to counsel, not the right to remain silent. ${ }^{80}$ This distinction is critical because, unlike the right to remain silent, the right to counsel can only be invoked by an affirmative act; that is, a suspect must break silence to assert the right. ${ }^{81}$ By articulating the requirements for assertion, the Court was, in its own words, attempting to provide law enforcement with clear procedural guidelines in the conduct of custodial interrogation. ${ }^{82}$ Such a clear standard for assertion is not necessary for the right to remain silent, which implies that suspects may exercise silence by simply not speaking. ${ }^{83}$ Put another way, the natural meaning of "remaining silent" is to continue in a state of abstaining from speech. ${ }^{84}$ Nevertheless, this seemingly self-evident proposition failed to find recognition in the lower courts grappling with the Davis decision.

By 2008, at least seven federal circuit courts extended Davis' "unambiguous statement" standard to the initial waiver stage. ${ }^{85}$ Some circuits also applied Davis to the initial question of whether a suspect properly invoked the right to remain silent. ${ }^{86}$ Although the Court in Davis clarified that suspects need not speak with the

\footnotetext{
${ }^{79}$ See Miranda, 384 U.S. at 468 (explaining the inherent pressures of custodial interrogations).

${ }^{80}$ See Davis, 512 U.S. at 454.

${ }^{81}$ See Berghuis v. Thompkins, 130 S. Ct. 2250, 2276 (2010) (Sotomayor, J., dissenting) (“Advising a suspect that he has a 'right to remain silent' is unlikely to convey that he must speak ... to ensure the right will be protected.... By contrast, telling a suspect "he has the right to the presence of an attorney['] . . . implies the need for speech to exercise that right.").

${ }^{82}$ See Davis, 512 U.S. at 458-59. See also McNeil v. Wisconsin, 501 U.S. 171, 178 (1991) (“[Miranda] requires, at a minimum, some statement that can reasonably be construed to be an expression of a desire for the assistance of an attorney. ...").

${ }^{83}$ BLACK'S LAW Dictionary 1416 (8th ed. 2004) (defining "silence" as "restraint from speaking").

${ }^{84}$ THE OXFORD AMERICAN COLLEGE DiCTIONARY 1276 (2002).

${ }^{85}$ Weisselberg, supra note 16, at 1579. See United States v. Johnson, 400 F.3d 187 (4th Cir. 2005); United States v. Lee, 413 F.3d 622 (7th Cir. 2005); United States v. Acosta, 363 F.3d 1141 (11th Cir. 2004); James v. Marshall, 322 F.3d 103 (1st Cir. 2003); United States v. Brown, 287 F.3d 965 (10th Cir. 2002); United States v. Syslo, 303 F.3d 860 (8th Cir. 2002); United States v. Suarez, 263 F.3d 468 (6th Cir. 2001).

${ }^{86}$ Weisselberg, supra note 16, at 1580. See, e.g., United States v. Ramirez, 79 F.3d 298, 305 (2d Cir. 1996) (assuming arguendo that a "parallel standard" to Davis applies to the right to remain silent).
} 
precision of an "Oxford don," ${ }^{, 87}$ lower courts have struggled to distinguish between the ambiguous and the unequivocal. ${ }^{88}$

The uncertainty brewing in the lower courts concerning the interrelationship of invocation and waiver and the proper application of Davis reached a boiling point in Berghuis v. Thompkins. ${ }^{89}$ The defendant in Berghuis was arrested in connection with a murder that occurred in Southfield, Michigan. ${ }^{90}$ During questioning, the suspect signed an advice-of-rights form, but remained generally uncommunicative ${ }^{91}$ and, in the officer's words, "largely silent." ${ }^{, 2}$ After three hours of unsuccessful questioning, the interrogating officer made one final attempt to elicit a response by asking a series of questions concerning the suspect's religious beliefs, culminating in, "Do you pray to God to forgive you for shooting that boy down?"93 The suspect's "yes" response was offered as evidence at his trial, which resulted in a conviction. ${ }^{94}$

In a 5-4 decision, the Supreme Court ruled that the Davis "unambiguous request" standard applies to the right to remain silent (that is, the suspect must unambiguously request to remain silent) and that Thompkins' "yes" response to the officer's question constituted a course of conduct indicating waiver. ${ }^{95}$ Berghuis clearly exemplifies the suspect's dilemma: even if Thompkins believed that he was exercising his right to silence by remaining silent for the first three hours of interrogation, his one-word response to the officer's question amounted to a waiver, which ultimately resulted in his conviction. Berghuis shows that an insufficient invocation often yields a valid waiver.

${ }^{87}$ Davis, 512 U.S. at 459.

${ }^{88}$ See People v. Stitely, 108 P.3d 182, 195 (Cal. 2005) (ruling that "I think it's time for me to stop talking" is ambiguous); State v. Henness, 679 N.E.2d 686, 695 (Ohio 1997) (concluding that "I think I need a lawyer because if I tell everything I know, how do I know I'm not going to wind up with a complicity charge?" is not a valid invocation).

${ }^{89} 130$ S. Ct. 2250 (2010).

${ }^{90} I d$. at 2256.

${ }^{91} I d$. at 2266.

${ }^{92} I d$. at 2256.

${ }^{93}$ Id. at 2257.

${ }^{94} I d$. at 2258.

${ }^{95}$ Id. at 2259-63. 
U N I V E R S I T Y O F P I T T S B U R G H L A W R E V I E W

PAGE

As the dissent in Berghuis noted, the plain language of Miranda contradicts the Berghuis majority's holding. ${ }^{96}$ First, the Court in Miranda observed:

The fact of lengthy interrogation ... before a statement is taken is strong evidence that the accused did not validly waive his rights. In these circumstances the fact that the individual eventually made a statement is consistent with the conclusion that the compelling influence of the interrogation finally forced him to do so. It is inconsistent with any notion of a voluntary relinquishment of the privilege. ${ }^{97}$

Furthermore, waiver may not be presumed simply from the fact that the police obtain a confession. ${ }^{98}$ Finally, "mere silence" in response to questioning is insufficient to establish waiver because a suspect's silence does not provide adequate assurances that he has "intelligently and understandingly" rejected the offer to exercise his rights. ${ }^{99}$ But the most glaring contradiction is the majority's conclusion that Thompkins' incriminating statement—his "yes" responseamounted to a "course of conduct indicating waiver," despite Miranda's warning that inculpatory statements alone are insufficient to establish waiver. ${ }^{100}$ A finding that Thompkins had not in fact waived his rights would have precluded the necessity of analyzing whether he invoked his right to silence, relieving the Court of the difficult question regarding Davis' applicability. ${ }^{101}$

The Berghuis Court's novel application of the implied waiver doctrine leaves criminal suspects in a tough position: as long as they understand the substance of the Miranda warning, any uncoerced statement establishes an implied waiver, even if the only statement a suspect makes is an inculpatory one. ${ }^{102}$ In effect, the Court has endorsed a jurisprudence of confession-as-waiver.

${ }^{96}$ Id. at 2268 (Sotomayer, J., dissenting).

${ }^{97}$ Miranda v. Arizona, 384 U.S. 436, 476 (1966).

${ }^{98} I d$. at 475 .

${ }^{99} I d$.

${ }^{100}$ Id. See also Berghuis, 130 S. Ct. at 2270 (Sotomayor, J., dissenting).

${ }^{101}$ Berghuis, 130 S. Ct. at 2273 (Sotomayor, J., dissenting).

${ }^{102} I d$. at 2262 (Sotomayer, J., dissenting). 


\section{MOVING FORWARD AFTER BERGHUIS: LIMITING IMPLIED WAIVERS AND CLARIFYING THE MIRANDA WARNING}

To ensure that the constitutional rights of criminal suspects remain as strongly protected today as they were in the immediate aftermath of Miranda, the postBerghuis implied waiver doctrine should be limited in scope, and suspects should be advised of the proper method of invoking their rights.

Under the original Miranda framework, waiver was only effective if "specifically made" by the accused. ${ }^{103}$ The exception recognized in Butler for waivers implied from the totality of the circumstances is narrow in scope to ensure that the original principles of Miranda continue to protect criminal suspects. ${ }^{104}$ Butler addresses the particular situation in which the accused who refuses to formally waive his rights nevertheless cooperates with the interrogators immediately after questioning begins, signaling a willingness to comply with the officer's request for a statement. ${ }^{105}$ It is from the accused's affirmative compliance from the onset of interrogation that waiver is inferred. Thus, despite recognizing a narrow exception to the Miranda rule, the Butler Court reaffirmed Miranda's original observation that "the fact of lengthy interrogation or incommunicado incarceration before a statement is made is strong evidence that the accused did not validly waive his rights."

In short, faithful application of Miranda is best achieved by applying the implied waiver exception only to those cases in which the accused cooperates from the beginning of questioning. This "initial compliance" reading of Butler vindicates Miranda's conclusion that the police-dominated interrogation setting works very quickly to compel the accused to speak. ${ }^{107}$ As discussed earlier, police have become especially proficient at employing techniques of persuasion, which are intended to undermine the defendant's will. ${ }^{108}$

\footnotetext{
${ }^{103}$ Miranda, 384 U.S. at 470.
}

${ }^{104}$ North Carolina v. Butler, 441 U.S. 369, 373 (1979) (noting that a heavy burden rests on the government to establish waiver and that the courts must presume that a defendant did not waive his rights).

${ }^{105} I d$. at 371 .

${ }^{106}$ Miranda, 384 U.S. at 476.

${ }^{107}$ Id. at 461 .

${ }^{108}$ See generally ZULAWSKI \& WICKLANDER, supra note 31; Leo \& White, supra note 27. 
PAGE

The initial-compliance application of Butler is not without precedent. In cases where the lower courts have found implied waivers, one common theme emerges: the accused demonstrated some commitment to speak with the interrogators from the commencement of questioning. ${ }^{109}$ For instance, lower courts have found implied waivers where the accused immediately responded to questions in the hope of revealing her insignificant role in the crime, ${ }^{110}$ where the accused agreed in writing to proceed without counsel before admitting that a photograph shown to him by the police contained his picture, ${ }^{111}$ and where the accused failed to invoke the right to silence by verbally refusing to identify himself and, shortly thereafter, confessing. ${ }^{112}$ In each of these cases, the defendant indicated some willingness at the outset to actively participate in the interrogation.

Finally, the initial compliance test ensures that waiver will never be presumed from the silence of the accused or from the fact that a confession is eventually obtained. ${ }^{113}$ The Berghuis case is illustrative in this regard. The defendant in Berghuis never indicated, in any manner, that he wished to cooperate or converse with the police; rather he sat nearly silent for almost three hours before making a one-word response to a spiritual inquiry. ${ }^{114}$ By establishing an all-encompassing implied waiver regime (in ruling that a one-word response after three hours of silence is a course of conduct indicating waiver), the Berghuis Court approved the elimination of Miranda's presumption against finding waiver from the accused's confession. ${ }^{115}$ This ruling contradicted numerous lower court decisions requiring waiver to be proven by something more than an inculpatory statement. ${ }^{116}$ By

${ }^{109}$ See generally United States v. Nichols, 512 F.3d 789 (6th Cir. 2008), abrogated on other grounds by United States v. Buford, 632 F.3d 264 (6th Cir. 2011); United States v. Washington, 462 F.3d 1124 (9th Cir. 2006); United States v. Velasquez, 626 F.2d 314 (3d Cir. 1980).

${ }^{110}$ Velasquez, 626 F.2d at 320.

${ }^{111}$ Washington, 462 F.3d at 1134.

${ }^{112}$ See Nichols, 512 F.3d at 798.

${ }^{113}$ Miranda v. Arizona, 384 U.S. 436, 475 (1966).

${ }^{114}$ Berghuis v. Thompkins, 130 S. Ct. 2250, 2256-57 (2010).

${ }^{115}$ Id. at 2270 (Sotomayer, J., dissenting).

${ }^{116}$ See United States v. Smith, 218 F.3d 777, 781 (7th Cir. 2000) (acknowledging implied waiver where the accused "immediately ... talk[ed] to the agents after refusing to sign a waiver form"); Bui v. DiPaolo, 170 F.3d 232, 240 (1st Cir. 1999) (finding implied waiver where the defendant engaged in a steady stream of speech with the police); United States v. Wallace, 848 F.2d 1464, 1475 (9th Cir. 1988) (refusing to recognize an implied waiver where the suspect remained silent for ten minutes before responding to questions). 
requiring the government to demonstrate that the accused has manifested some consent to participating in questioning, the initial compliance standard ensures that any incriminating statement is the product of the accused's free will, which is the hallmark of the Miranda waiver system. ${ }^{117}$

In addition to confining the application of the implied waiver doctrine, suspects taken into custody should be advised that if they wish to exercise their right to remain silent, they must make an "unambiguous request" addition to the standard Miranda warning incorporates the Court's determination in Berghuis that the Davis unambiguous-request standard applies to the right to remain silent, even though Davis—on its face—only governs post-waiver invocations of the right to counsel. ${ }^{119}$

There are two primary reasons to incorporate the "unambiguous" language into the familiar Miranda warnings. First, it ensures that criminal suspects are aware of the proper method for exercising their constitutional rights, in the same way that the standard Miranda warnings ensure that suspects are aware of their rights. ${ }^{120}$ Second, because there is great uncertainty in the lower courts about what constitutes an unambiguous statement or assertion, ${ }^{121}$ it is essential that the accused is advised of the need to be explicit, particular, and definite. Statements containing modifiers or hedges are especially likely to be insufficient under Davis. ${ }^{122}$ Indeed, as previously noted, when a suspect makes an ambiguous request that he believes to be an assertion of his rights, the interrogator's refusal to end questioning may

${ }^{117}$ See Miranda, 384 U.S. at 536 (White, J., dissenting) (noting that it is the free will of the defendant that is implicated by the prohibition against compulsive interrogation).

${ }^{118}$ Berghuis, 130 S. Ct. at 2260.

${ }^{119}$ See Davis v. United States, 512 U.S. 452, 461 (1994) (“[A]fter a knowing and voluntary waiver . . . law enforcement officers may continue questioning until and unless the suspect clearly requests an attorney.").

${ }^{120}$ See Miranda, 384 U.S. at 444 ("[Government must adopt] fully effective means ... to inform accused persons of their right to remain silent and to assure a continuous opportunity to exercise it.”).

${ }^{121}$ See, e.g., People v. Stitely, 108 P.3d 182, 196 (Cal. 2005) (holding that suspect's statement, "I think it's about time for me to stop talking," is not unambiguous); Clark v. Murphy, 331 F.3d 1062, 1069 (9th Cir. 2003) (ruling that "I think I would like to talk to a lawyer" is not unambiguous), overruled on other grounds by Lockyer v. Andrade, 538 U.S. 63 (2003); United States v. Mills, 122 F.3d 346, 347 (7th Cir. 1997) (incorporating the facts as originally articulated in United States v. Banks, 78 F.3d 1190 (7th Cir. 1996), and concluding that "Get the f - out of my face. I don't have nothing to say." is not a valid invocation).

${ }^{122}$ See Marcy Strauss, Understanding Davis v. United States, 40 LoY. L.A. L. ReV. 1011, 1040-43 (2007) (describing how courts have found that phrases with hedges and modifiers are ambiguous). 
U N I V E R S I T Y O F P I T T S B U R G H L A W R E V I E W

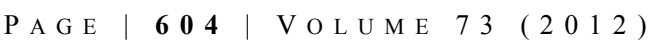

lead the suspect to believe that further objection is pointless. ${ }^{123}$ Interestingly, the Davis Court, which held that defendants must assert the right to counsel in an unambiguous manner, nevertheless acknowledged:

When a suspect understands his (expressed) wishes to have been ignored (and by hypothesis, he has said something that an objective listener could "reasonably," although not necessarily, take to be a request), in contravention of the "rights" just read to him by his interrogator, he may well see further objection as futile and confession (true or not) as the only way to end his interrogation. ${ }^{124}$

In assessing how the extension of Davis may affect invocation of the right to remain silent, Professor Marcy Strauss has identified eights types of statements often interpreted by the courts as ambiguous despite a suspect's intent to invoke the right:

(1) questions concerning the right; (2) use of modal verbs like "maybe," "might," or "could;" (3) hedges; (4) simple silence; (5) requests to do something else besides talking; (6) temporally vague comments about the willingness to talk; (7) comments that indicate a desire not to talk about specific topics or not to say something incriminating; (8) comments that become ambiguous because of other statements or conduct. ${ }^{125}$

Because locating the distinction between clear and ambiguous statements requires a subjective inquiry, ${ }^{126}$ suspects should be placed on notice that they must invoke their rights with particularity.

Incorporation of the required means to exercise the right to silence into the Miranda warning also reflects practical concerns. It is exceedingly unlikely that the Court will soon reverse itself on the extension of Davis to the right to remain silent. ${ }^{127}$ Because a suspect is unlikely to understand that he must first speak in

${ }^{123}$ Berghuis, 130 S. Ct. at 2278 (Sotomayer, J., dissenting).

${ }^{124}$ Davis, 512 U.S. at $472-73$.

${ }^{125}$ See generally Marcy Strauss, The Sounds of Silence: Reconsidering the Invocation of the Right to Remain Silent Under Miranda, 17 WM. \& MARY BILl RTS. J. 773, 788-802 (2009).

${ }^{126}$ Berghuis, 130 S. Ct. at 2277 (Sotomayer, J., dissenting).

${ }^{127}$ See Fed. Election Comm'n v. Wis. Right to Life, Inc., 551 U.S. 449, 534 (2007) (Souter, J., dissenting) ("The Court (and, I think, the country) loses when important precedent is overruled without good reason ...."). 
order to remain silent, ${ }^{128}$ an enhanced Miranda warning guards against the possibility that a suspect will unwillingly waive his rights after trying futilely to assert them. ${ }^{129}$

\section{Conclusion}

If the purpose of Miranda is to provide law enforcement with clear procedural guidelines in the conduct of custodial interrogation, while alleviating suspects of the inherent pressures of police questioning, ${ }^{130}$ then it must be considered why, after forty-five years, the procedural guidelines are not quite clear at all and the inherent pressures of police questioning have been replaced by new pressures on suspects to invoke their rights in a narrowly-circumscribed manner. How far can police go in extracting confessions? If three hours of persistent questioning is constitutionally permissible, ${ }^{131}$ is six or eight or eighteen hours? Which statements of invocation by a suspect are sufficiently unambiguous? Can police continue questioning even when suspects make unequivocal requests to exercise their rights?

Perhaps the most provocative question after Berghuis is this: absent an unequivocal assertion of the right to silence, is there anything a suspect can say or do that does not amount to a course of conduct indicating waiver? If an incriminating, one-word response after three hours of silence signals a suspect's willingness to surrender the right, what words or actions by the accused will not amount to an implied waiver?

These are the questions that the lower courts now face. In the meantime, thousands of interrogations will now be governed by a new set of rules that leave suspects uninformed about the proper method of exercising their rights, while providing law enforcement with incentives to persist in questioning in the hope that any slight response from the accused will be deemed an implied waiver. The consequences could not be more real or severe: Berghuis now sits in a jail cell for the remainder of his life, in large part because he once said "yes." If the right to remain silent does not actually permit one to remain silent, then we all have a right to know about it.

\footnotetext{
${ }^{128}$ Berghuis, 130 S. Ct. at 2276 (Sotomayer, J., dissenting).

${ }^{129}$ See id. at 2278.

${ }^{130}$ Miranda v. Arizona, 384 U.S. 436, 442-46 (1966).

${ }^{131}$ See Berghuis, 130 S. Ct. at 2257.
} 